\title{
多層マウンド上のケーソンと波の \\ 非線形相互作用に関する研究 \\ NONLINEAR INTERACTIONS BETWEEN WAVES AND A CAISSON \\ CONSTRUCTED OVER A MULTI-LAYERED BASE
}

\author{
水谷法美1・モスタファアイマン2 \\ Norimi MIZUTANI and Ayman M. MOSTAFA \\ 1正会員 工博 名古屋大学大学院助教授 工学研究科土木工学専攻( \\ 2正会員 博士(工学) 名古屋大学大学院助手 工学研究科土木工学専攻 (同上)
}

\begin{abstract}
A study has been conducted to investigate the nonlinear interactions among waves, composite breakwater and a multi-layered base. The problem has been simulated numerically by two models, BEMFEM model and poro-elastic FEM model. These models, developed by the authors, can simulate the nonlinear wave field and its interactions with the porous media. Modifications have been made in the models to account for the multi-layered base and applications have been made to various configurations and properties of the breakwater. It has been found that the nonlinear effects become more significant in case of a high base and the fine material of the base may suffer from tensile stresses. The base may also fail at smaller wave heights than that needed for causing a failure in the caisson.
\end{abstract}

Key Words : Wave-structure-foundation nonlinear interaction, multi-layered base, composite breakwater, stability analysis

\section{1. 緒言}

混成堤は日本で最も広く採用されている防波堤の 一形式である. 最近, 混成堤の動的な耐波安定性を 解析する手法の一つとして, 海底地盤の波浪応答ま で含めた波・構造物・海底地盤の相互作用問題の数 值解析手法がいくつか提案されている1).2). 一般的 な混成堤は, いくつかの材質により複数の層で構策 された捨石マウンド上に鈶直壁を持つケーソンを有 する構造であるが, これまでの解析は, 波・構造物 のみの相互干渉問題も含め, マウンドを単層の均一 透水性マウンドとして取り扱っている1)-3).

一方, 最近ではマウンドの天端を高くし, ケーソ ンを小さくする高基混成堤が提案されている4), 5).

これにより, 建設コストの軽隇が可能であるだけで なく, ケーソンの小型化により耐波安定性を向上さ すことも可能である4), 5).マウンドの天端水深が浅く なると, 波と構造物の相互作用における非線形性は 強くなると同時に, マウンドの層の性状を含めた多 首系の影響も重要になると考えられる.

また, マウンドの建設コストを軽減さすために, 捨石マウンドの粒径を小さくすることが考えられる.
マウンド構成材自身の耐波安定性が確保されれば, マウンド内部の間隙水圧などは粒径が小さいほど鈶 直方向の減衰が大きいという利点もある. したがっ て, 波・構造物の相互作用問題は, マウンドを多層 系として扱ってこれらの効果を検討しておく必要が ある. しかしながら，これまで多層系マウンドを考 慮した波・構造物の非線形相互作用問題はほとんど 解析されておらず，その実態は解明されていない.

本研究は, 著者らの開発した数值解析手法)を多 層系マウンドを有する混成堤の非線形相互作用問題 へ拡張し, 多層系マウンドがケーソンの耐波安定性 に及ぼす影響や，多層系マウンド自身の波浪応答と それにともなう不安定性について考究するものであ る.

\section{2. 数值解析}

図-1に本研究で対象とする構造物の概略を示す. 構造物は, 基礎マウンド上に構築された捨石マウン ドとその上に設置される不透過ケーソンにより構筑 される. 簡単のため, 基礎マウンドは二首からなり, 下層は上層よりも粒径の小さい材質で構策されると 


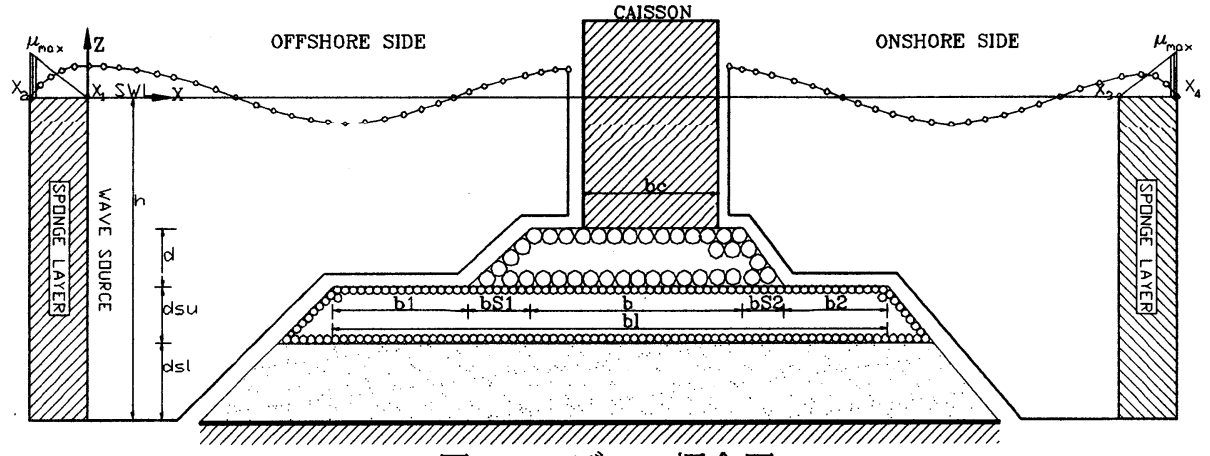

図-1モデルの概念図

する.

まず，計算領域を，構造物の沖側と岸側の波動場 と基礎マウンドと捨石マウンドで構成される透水層 に分ける.

構造物の沖・岸側の波動場領域では, 非圧縮性完 全流体の非回転流れを仮定し，速度ポテンシャルと 水位変動を未知数として境界要素法による定式化を 行う。一方, 透水層内部の流れ場は非圧縮性流体の 回転運動を仮定し, 水平・鉛直流速 $\mathrm{u}$ と $\mathrm{w}$, および圧 力pを直接有限要素法によって定式化する. さらに, 波動場と透水層の境界面上で, 流量と圧力の連続条 件を課し, 両者を同時に解いて波動場と流れ場の時 間発展の計算を行うBEM-FEMモデルで解析する1).

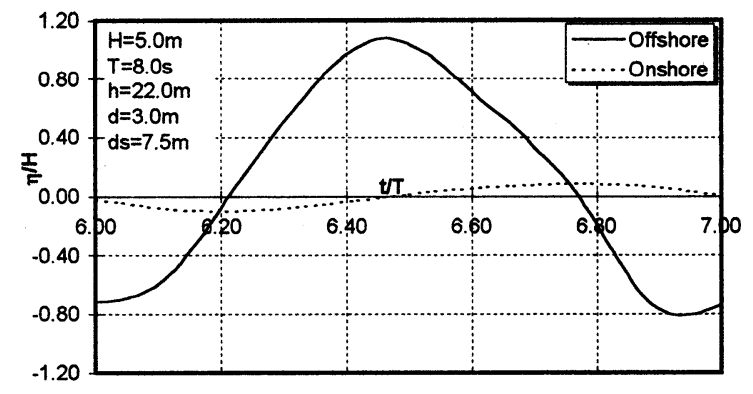

図-2 ケーソン前·後面の水位変動の時間変化の例

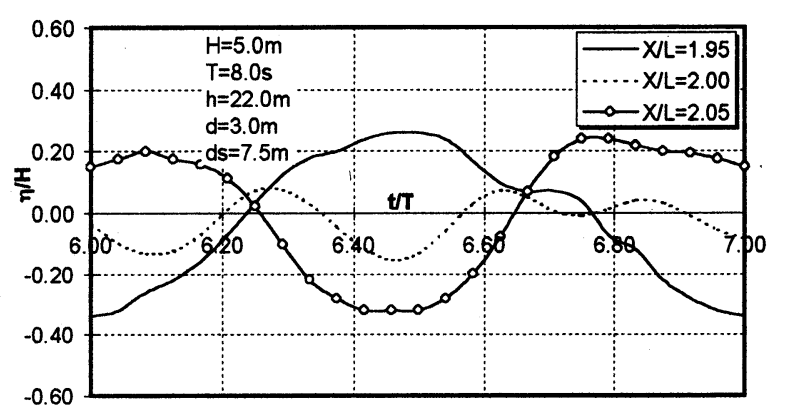

図-3＼cjkstart節の近傍におけける水位変動の時間変化の例

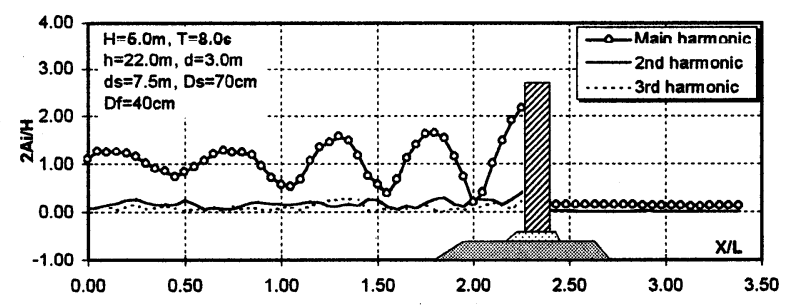

図-4 水位変動の高次周波数成分の空間変化の例
さらに, 透水層では, BEM-FEMモデルで計算した 透水層表面での圧力を入力 とし，Biotの方程式のに基づ くporo-elastic FEM モデルで 波浪応答の解析を行う ${ }^{1)}$.

計算条件は以下のように 設定した。静水深を $\mathrm{h}=22 \mathrm{~m}$ とし，入射波は周期 $\mathrm{T}=8 \mathrm{~s}$ の 規則波とした。ただし，波 高を1mから5mまで変化させ た。これはStokes波の 2 次か ら3次近似解に相当する．捨石マウンド高さは $\mathrm{d}=3 \mathrm{~m}$, 二層で構成される基礎マウンド高さは $\mathrm{ds}=7.5 \mathrm{~m}$ （上 層厚 $\mathrm{dsu}=3.0 \mathrm{~m}$ ，下層厚 $\mathrm{ds}=3.5 \mathrm{~m} ）$ とし，法面勾配は 沖側が $1 / 2$ ，岸側が $1 / 1.5$ とした。また，構成材の中 央粒径を，特別なケースを除き，捨石マウンドで $\mathrm{Ds}=70.0 \mathrm{~cm}$ ，基礎マウンド上層部で $\mathrm{Df}=20.0 \mathrm{~cm}$ ，基礎 マウンド下層部で $0.1 \mathrm{~cm}$ とした.

\section{3. 結果と考察}

\section{（1）水位変動}

図-2にケーソン前後の水位変動の時間変化を例示 する．ケーソン前面（沖側）では波の重複により波 高は入射波高の約 2 倍程度となる。一方，ケーソン 後面（岸側）での波高は入射波高の約 0.2 倍と小さ いものの無視できない大きさの波が透水層を通じて 港内側に伝播しうる.

図-3と図-4に各点の水位変動を調和解析を行って 求めた 3 次までの調和成分の振幅の空間変動と重複 波の節の位置の近傍における水位変動の時間変化を 例示する. ケーソン前面では 高次の調和成分の混 在が顕著であり，特に節の位置では3次の調和成分 も有意な大きさとなっていることがわかる.

一方, 構内側では, 水位変動は有意な大きさであ るが，高次周波数成分は港内側ではほとんど認めら れず，透水層が高次周波数成分のフィルターの機能 を果たしているといえる.

（2）水粒子速度

沖側の基礎マウンド表面（斜面上と天端上）にお ける接線流速の時間変化を図-5に示す。また，基礎

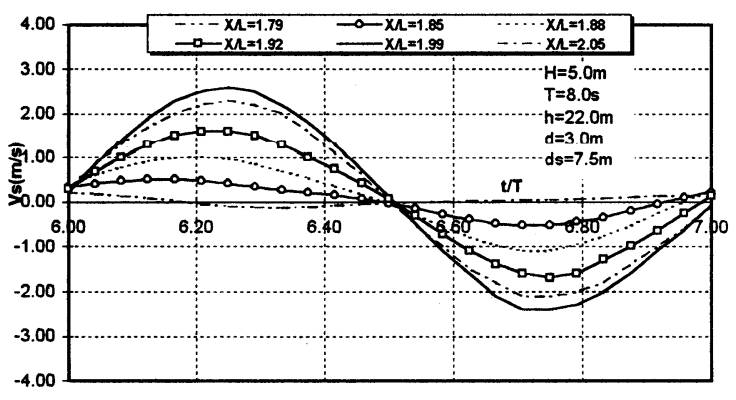

図-5，基礎マウンド表面の接線方向流速の時間変化 


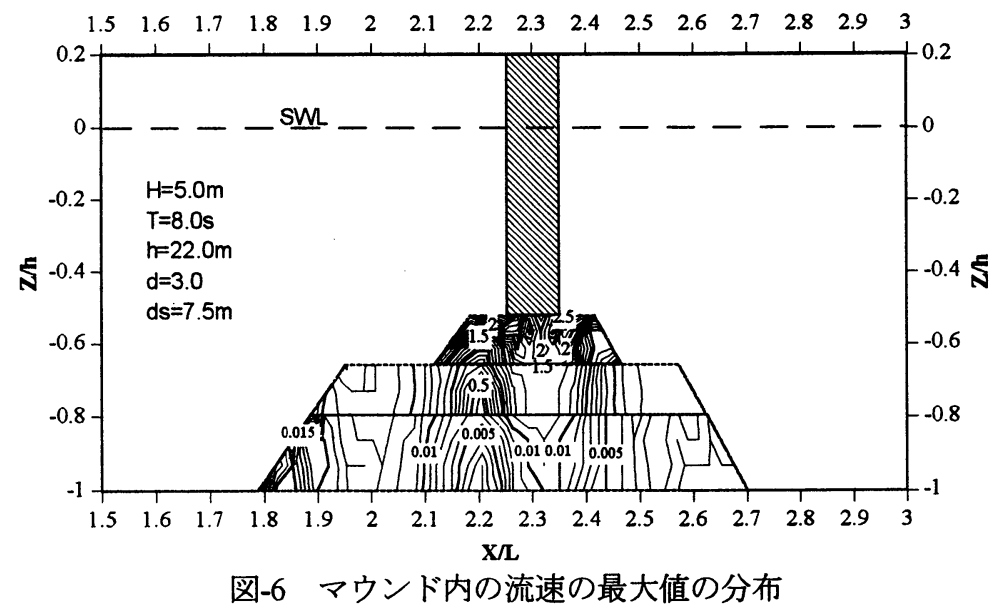

図-6 マウンド内の流速の最大值の分布

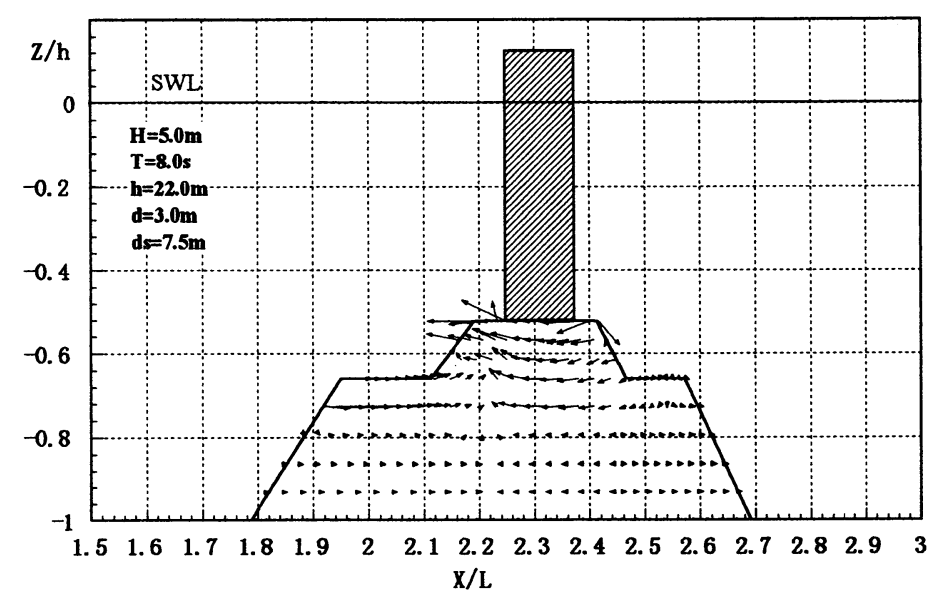

図-7＼cjkstart流速ベクトルの空間分布の例

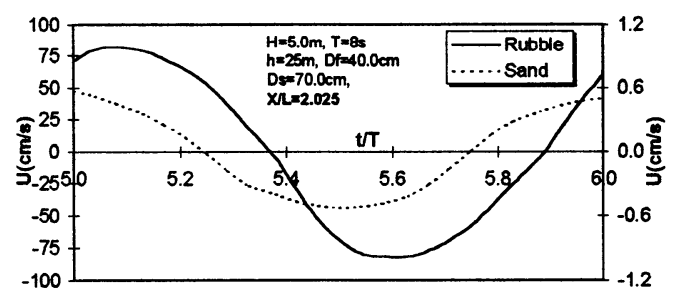

(a) $\mathrm{Df}=40 \mathrm{~cm}$

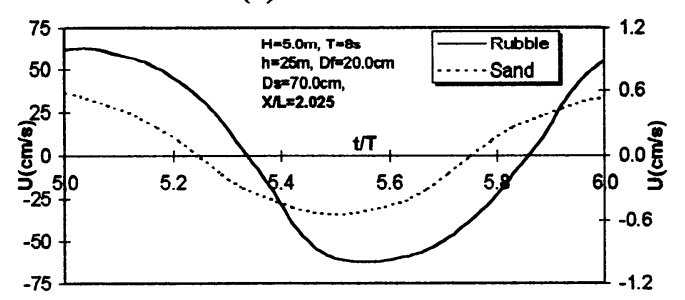

(b) $\mathrm{Df}=20 \mathrm{~cm}$

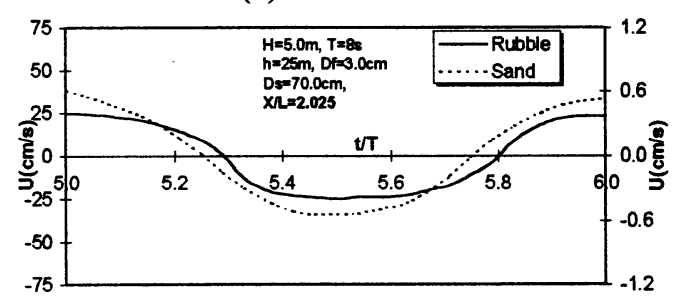

(c) $\mathrm{Df}=3 \mathrm{~cm}$

図-8 基礎マウンド境界面での水平方向流速
マウンド，および捨石マウンド内における 実流速の最大值の空間分布を図-6に，また， ケーソン前面の水位が谷の位相での流量流 速ベクトルの空間分布を図-7にそれぞれ示 す. 基礎マウンド内の上層部における流速 は，下層部の流速に比べて非常に大きく なっていることが明瞭に認められる．この 不連続性は，透水層の粒径やそれにともな う抵抗の差によって生じる結果であり，本 計算手法が境界面で接線方向流速の連続条 件を課していないために再現が可能となっ ている．上層部の粒径Dfが流速に及ぼす影 響を調べるために，異なるDfに対して基礎 マウンド内の境界面における上層と下層の 水平方向流速の時間変化を比較したのが図 -8である.

Dfが小さくなるにしたがい，上層の流速 は小さくなる。しかし，下層の流速はDfが 10倍以上変化してもほとんど差は生じない. また，Dfが小さい場合には，上層と下層で 流速に大きな位相差はないが，Dfが大きく なると両層における流速に大きな位相差生 じる.この位相差は，上層の速い流れによ る下層表面の洗掘や吸い出しなどの破壊を 助長する一要因でもあると考えられ，この ような粒径の異なる層間には, ジオテキス タイルのようなシート等による保護工の設 置の検討が必要と考えられる.

（3） ケーソンの作用波力

ケーソン表面の圧力の積分により求めた波力と転 倒モーメントを図-9に例示する．なお，ケーソン前 面の作用波力FXLは岸向きが正, 後面の波力FXRは 沖向きが正である．ケーソン前面の作用波力は非線

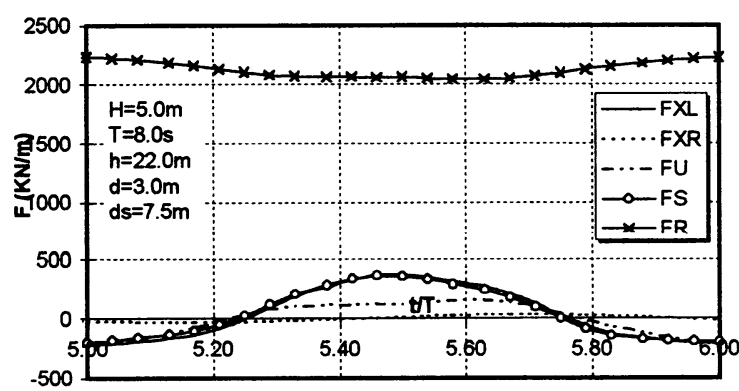

図-9 ケーソンの作用波力の時間変化

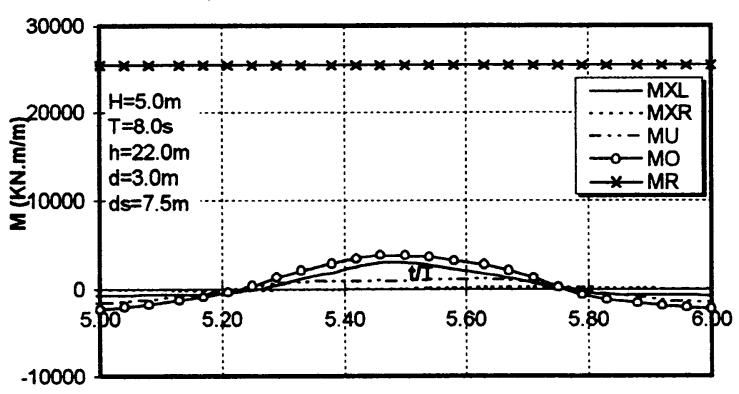

図-10 後趾端周りの転倒モーメントの時間変化 
形性を帯びた波形となっており，正方向の波力は負 方向波力の約 2 倍程度の大きさになる. 一方, 後面 のFXRには, FXLとの間に位相差があり, また, 值 はFXLの約10\%程度である.ただし, 波形は上下非 対称な波形になっている.これらは, 波動場に含ま れる高次周波数成分の効果によると考えられる.

一方, 揚圧力FUもやはり非線形な挙動を示す. FUの大きさはFXLの約40\%〜 50\%であり, また, FXLとの間に若干の位相差がある. ただし, 揚圧力 に関しては, 負の值, すなわちマウンドに向かう力 が上向きの值よりも大きい. これは, 主にケーソン 前面に作用する岸向きの波力がケーソンを押しつけ る作用をすることによると考えられる.

図-10はケーソン後趾端周りの転倒モーメントを 例示したものである. なお, 図中, MXL, MXRと MUはそれぞれFXL, FXRとFUによって生じる後趾端 周りのモーメントの成分である. なお, 基本的に時 計回りを正としているが，MXRのみ反時計回りを 正としている.

正の MXLは負の值よりも非常に大きくなってい るが, MXRとMUは両方向とも同程度の值である.

また, MXLの時間変化はFXLと異なり, クノイド波 のような形状となる. MUは, ケーソン前面水位が 最高点に達する位相の前後でしばらくの間ほぼ同じ 值をとり続ける.これはケーソン下部の非線形成分 波の干渉によると考えられる. なお, 同時に計算し た抵抗力FR, 抵抗モーメントMRから計算される

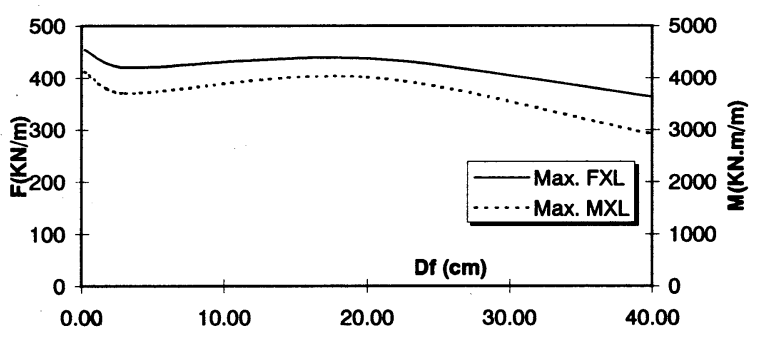

(a) FXL, MXL

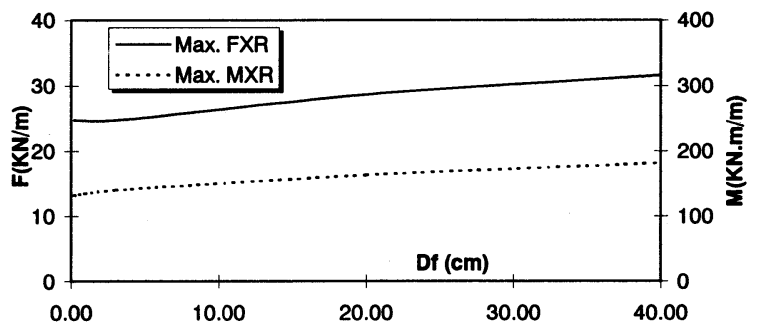

(b) FXR, MXR

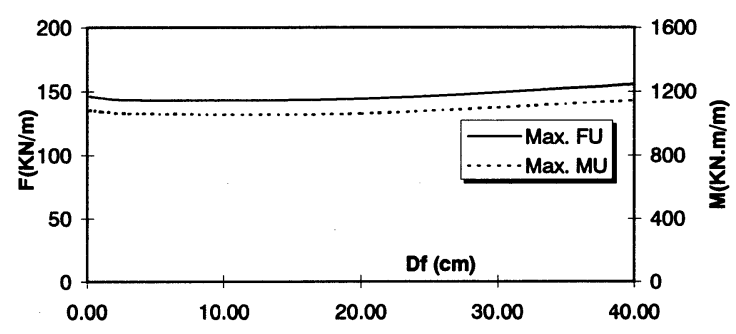

(c) FU, MU

図-11 波力とモーメントに及ぼすDfの効果
ケーソンの滑動と転倒に対する安全率から本計算条 件ではケーソンは充分安定であることが確認された.

基礎マウンドの上層部の粒径 Dfが波力に及ぼす 効果を図-11に示す. Dfを $0.2 \mathrm{~cm}$ から $40.0 \mathrm{~cm}$ に増加さ せた場合，FXLとMXLは急激に減少した後，入射波 と反射波の干渉により若干増加する。 そして，その 後再び徐々に減少する. 一方, ケーソンの反対側に 作用するFXRとMXRは, Dfの増加にともない増加 する.これらの結果は，Dfが大きくなることにより， 港内側への透過波が大きくなると同時に，ケーソン 前面での反射波が減少することによる．これに対し て, 揚圧力FUとそれによるMUはDfの増加に対して わずかに増大する程度である.

上記Dfの効果は捨石マウンドの粒径Dsの場合も同 様に現れる. 図-12は, Dsを $20 \mathrm{~cm}$ から70cmまで増加 させた場合の波力とモーメントの変化を示した例で ある. FXLとMXLはDsが増加するにしたがって，多

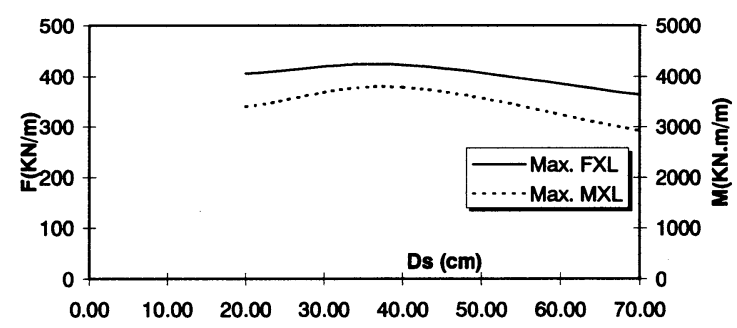

(a) FXL, MXL

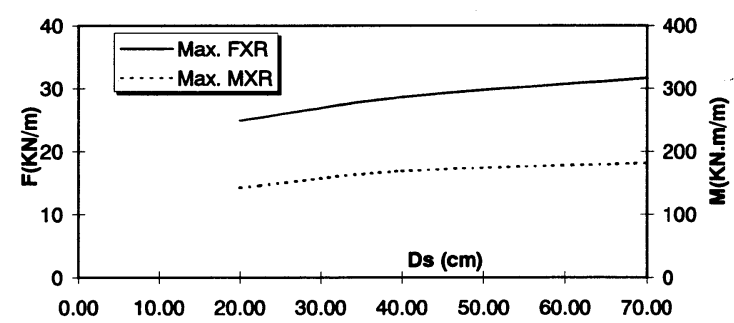

(b) FXR, MXR

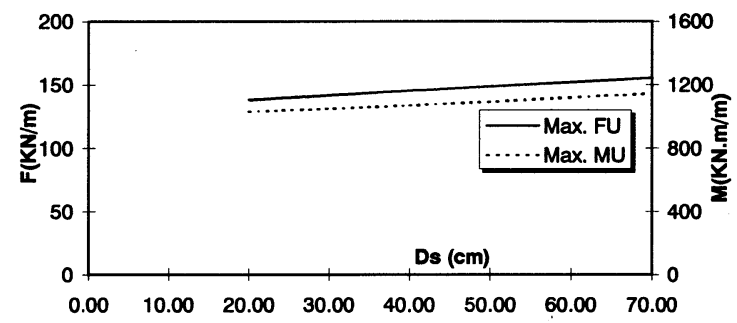

(c) FU, MU

図-12 波力とモーメントに及ぼすDsの効果

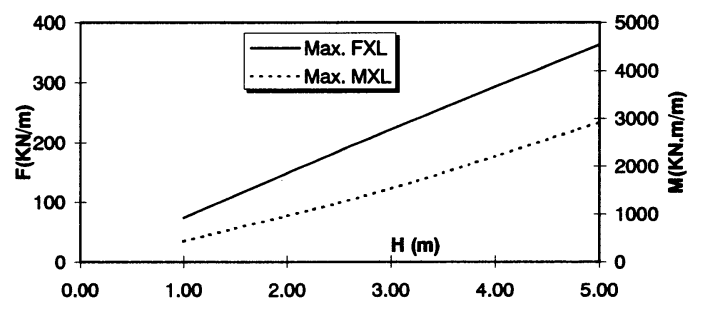

図-13 FXL，MXLに及ぼす波高の効果 


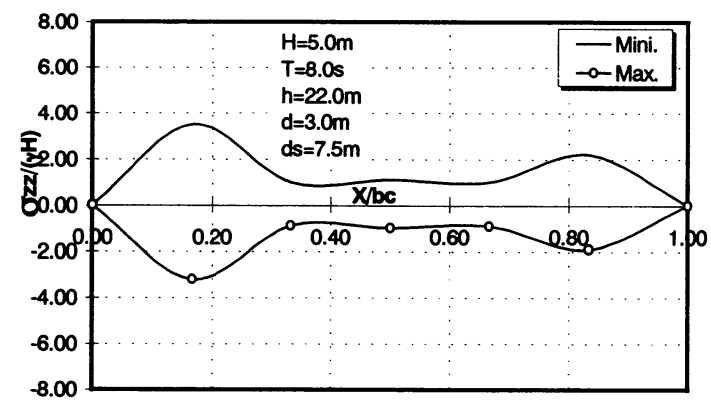

図-14 ケーソン下面に作用する鈶直有効応力

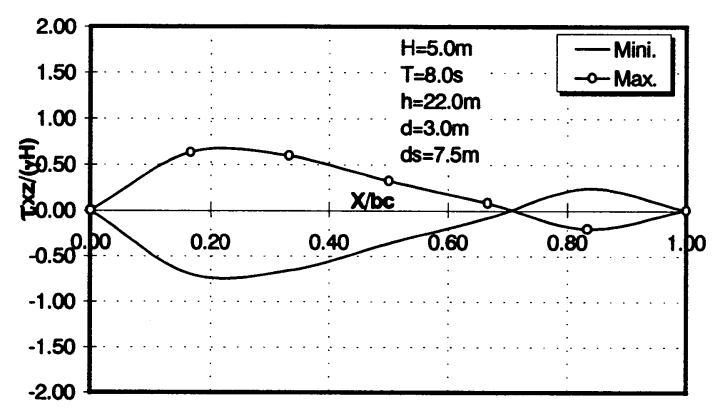

図-15ケーソン下面に作用するせん断力

少ではあるが一度増加し, その後滅少する. しかし, FXRとMXRはDsの増加とともに大きくなる.これ らの結果もDfの場合と同様, 反射波と透過波の差に よる. 一方, FUとMUは, Dsが大きくなると若干大 きくなる.これは捨石マウンド内の流速の振幅がDs が大きくなるにともない増大し，これにともなって
圧力の振幅も増大するためであると考えられる.

図-13は, 波高の増大にともなう波力とモーメン トの変動特性について, FXLとMXLの場合の結果を 示したものである. 波力に対しては, ほぼ線形的な 増加傾向を示しているが, モーメントについては, わずかであるが下に凸となる変動特性となっている. これは, 水位変動の効果と考えられる.

\section{（4）マゥゥンド内の応力と間隚水圧}

ついでporo-elasticモデルによる堤体内の応力と変 位について考察する. なお, せん断弾性係数は, 捨 石マウンドは $2 \times 10^{7} \mathrm{~N} / \mathrm{m}^{2}$ で一定としたが, 基礎マウ ンドは, 深さ方向に変化させ, 最上層の $2 \times 10^{7} \mathrm{~N} / \mathrm{m}^{2}$ から最下層の $5 \times 10^{7} \mathrm{~N} / \mathrm{m}^{2}$ まで增加させて計算を行っ た. また, 空隙の飽和度Srは他の研究》 と同様, 90 〜100\%の間で変化させた. さらに, 異なる層の等 価透水係数はMizutaniら ${ }^{8)}$ にしたがって計算した.

図-14にケーソン下面に作用する鈶直有効応力を 示す. 通常の静的な解析で使われるような線形的な 変化とは異なり, 鈶直有効応力は, ケーソン両端近 傍で極值をとる双峰型の分布となる.この結果は静 的な解析と異なる結果であり, したがって, マウン ド内の波浪応答は, マウンドの変位を考慮した解析 が必要であることが指摘できる.

一方，ケーソン下面に作用するせん断力は，図15に例示するように, 後趾端から中央にケーソン幅 の約 $1 / 3$ 程度離れた位置でゼロとなる非対称な分布 形となる.

図-16に飽和度Srが100\%と90\%に対する最 大間隙圧の空間分を示す．水平方向の圧力 勾配が捨石マウンド法先付近とケーソン下 部の全般で大きくなる.さらに飽和度が小 さくなると基礎マウンドの沖側法面で圧力 勾配が大きくなる.

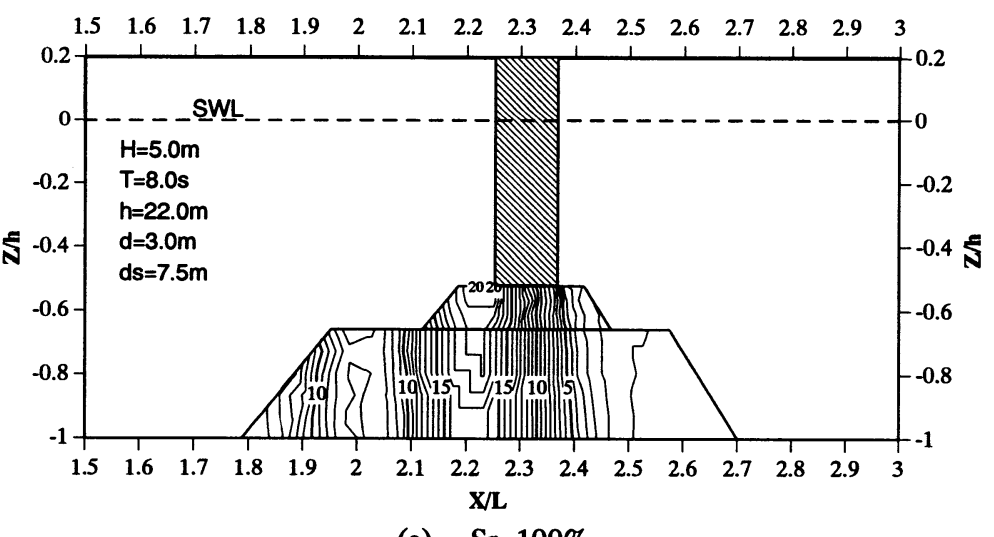

(a) $\mathrm{Sr}=100 \%$

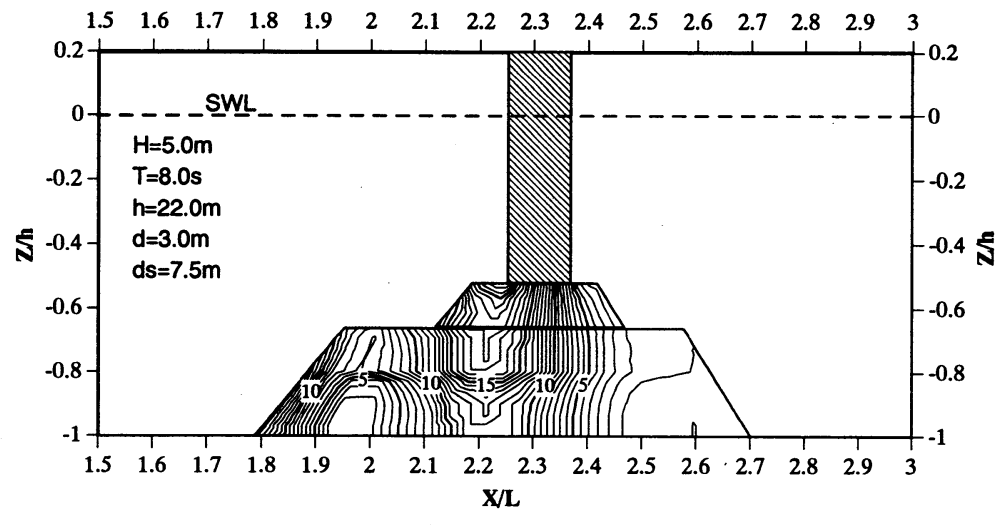

(b) $\mathrm{Sr}=90 \%$

図-16 マウンド内の間隙水圧の分布
つぎに，マウンドの不安定性が生じる一 原因である引張力の発生領域について, 基 礎マウンドを取りあげて検討する. 図-17に 高さの異なる3地点における水平有効応力 の時間変化を示す. 捨石マウンド法先にあ

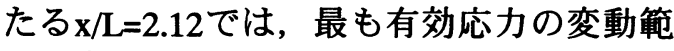
囲が大きい. そして, 法先から沖側にかけ て引張力が発生する. 応力の振幅はマウン ド表面の $\mathrm{z}=-14.5 \mathrm{~m}$ の位置が最大で, $\mathrm{z}$ が小さ くなる,すなわち, マウンド内部に進むに したがって応力の振幅は小さくなり, 引張 力の発生領域は狭くなる. そして, 例示し たケースでは, 表面から約 $1.5 \mathrm{~m}$ の深さで引 張力の発生は無くなる.この引張力の発生 は, 粒子間の拘束力の消失を意味するもの で, マウンド構成材の粒径が小さい場合は, 局所洗掘などの不安定性の原因になりうる 1)もので, 最終的にはケーソンの破壊にま でつながる可能性もある. 既述したように, この条件においては, ケーソンは, 滑動, 


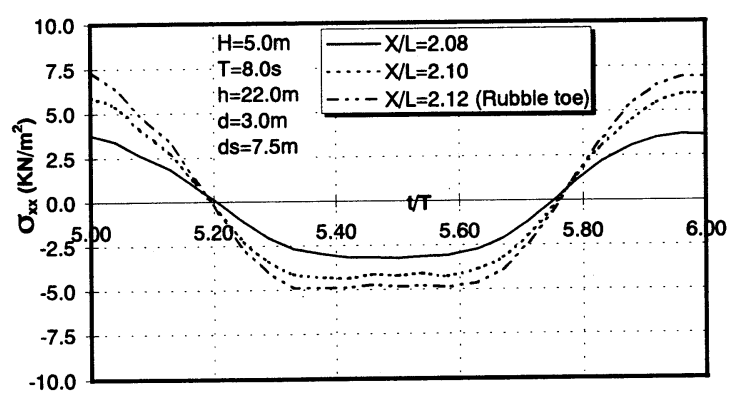

(a) $\mathrm{z}=-14.5 \mathrm{~m}$

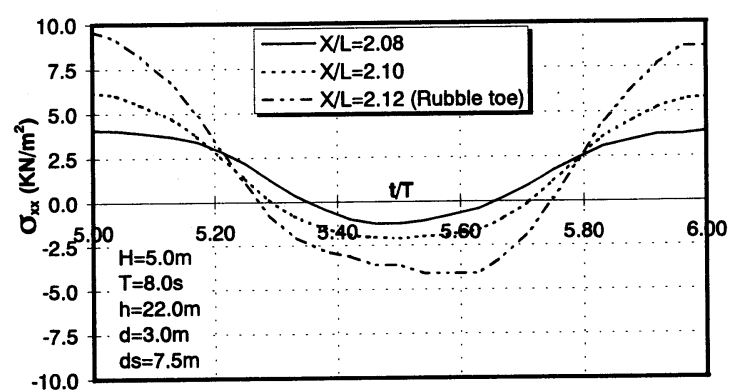

(b) $z=-15.25 \mathrm{~m}$

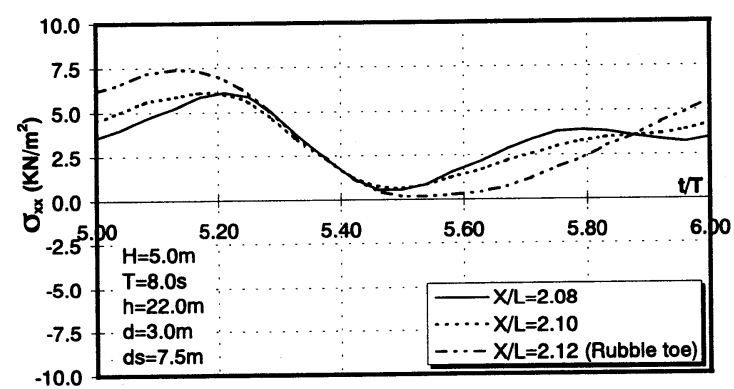

(c) $\mathrm{z}=-16.0 \mathrm{~m}$

図-17基礎マウンドの水平有効応力

転倒, さらには過剩応力による破壊に対して安全で あった. したがって，ケーソンの限界よりも小さい 波でマウンドが破壊する可能性も充分考えられ，基 礎マウンドも構築に際して, マウンドの波浪応答を 十分検討しておく必要が指摘できる.

\section{4. 結論}

本研究では, 波, 混成堤と多層系マウンドの非線 形相互作用について検討を加え, 非線形波変形, ケーソンに作用する波力とマウンド内の応力場につ いて考究した. 本研究の成果を以下に要約する.

1) マウンド上の混成堤近傍では, 高次周波数成分の
波動成分が有意な大きさとなり, 非線形性を考慮 した波浪変形計算が必要である.

2) ケーソン下部の捨石マウンドと基礎マウンド上層 部では流速は大きく, その下層表面の粒径の細か い粒子の安定性に影響を及ぼす可能性がある.

3) 岸側のケーソン壁面に作用する波力は, マウンド 粒径が小さくなり，マウンドの透水性が低くなる ほど小さくなる.

4) 波高の増大は, 揚圧力の高次周波数成分に強く影 響を及ぼすが，岸側の壁面の波力には明瞭に影響 を及ぼさない。

5) ケーソン前面に形成される部分重複波の節にあた るマウンドでは, 有意な深さまで引張力が発生し うる.これにより，混成堤の安定性は大きく減少 する.

6) 基礎マウンドの破壊は, ケーソンの破壊よりもよ り小さな波で発生しうる.

\section{参考文献}

1) 水谷法美・Mostafa, A.M. : 混成堤および潜堤の基礎地 盤の波浪応答と局所洗掘に関する研究, 海岸工学論文 集, 第45巻, pp.881-885, 1998.

2) Mase, H., Sakai, T. and Sakamoto, M. : Wave-induced porewater pressures and effective stresses around breakwater, Ocean Eng., Vol.21, No.4, pp.361-397, 1994.

3) Sulisz, W. : Numerical modelling of the stability of rubble bases, Proc. 23rd Int. Conf. Coastal Eng., ASCE, pp.1799$1809,1992$.

4) 高橋重雄・鈴木健二朗・三浦裕信・斉藤祐一 : 低天端 型防波護岸の越波に関する一実験, 海洋開発論文集, Vol.11, pp.193-198, 1995.

5) 下迫健一郎 - 高橋重雄 - 斉藤祐一 - Muttray, M. Oumerachi, H.・細川泰廣 : 高基混成堤の水理特性およ び而波安定性に関する大型模型実験, 海岸工学論文集, 第44巻, pp.826-830, 1997.

6) Biot, M. A. : General theory of three-dimensional consolidation, J. Appl. Phys., Vol.12, pp.155-164, 1941.

7) Hsu, J.R.C. and Jeng, D.S. : Wave-Induced soil response in an unsaturated anisotropic seabed of finite thickness, Int. J. for Numerical and Analytical Methods in Geomechanics, Vol.18, pp.785-807, 1994.

8) Mizutani, N., Mostafa, A. and Iwata, K. : Numerical modelling of the nonlinear dynamic interaction between composite breakwaters and waves, Jour. of Hyd., Coast. \& Env. Eng., JSCE, Vol.614, pp.121-133, 1999.

(1999.4.19受付) 